\title{
The Jackfruit (Artocarpus heterophyllus Lam.) in Florida ${ }^{1}$
}

J.H. Crane, C.F. Balerdi, and R.J. Campbell ${ }^{2}$

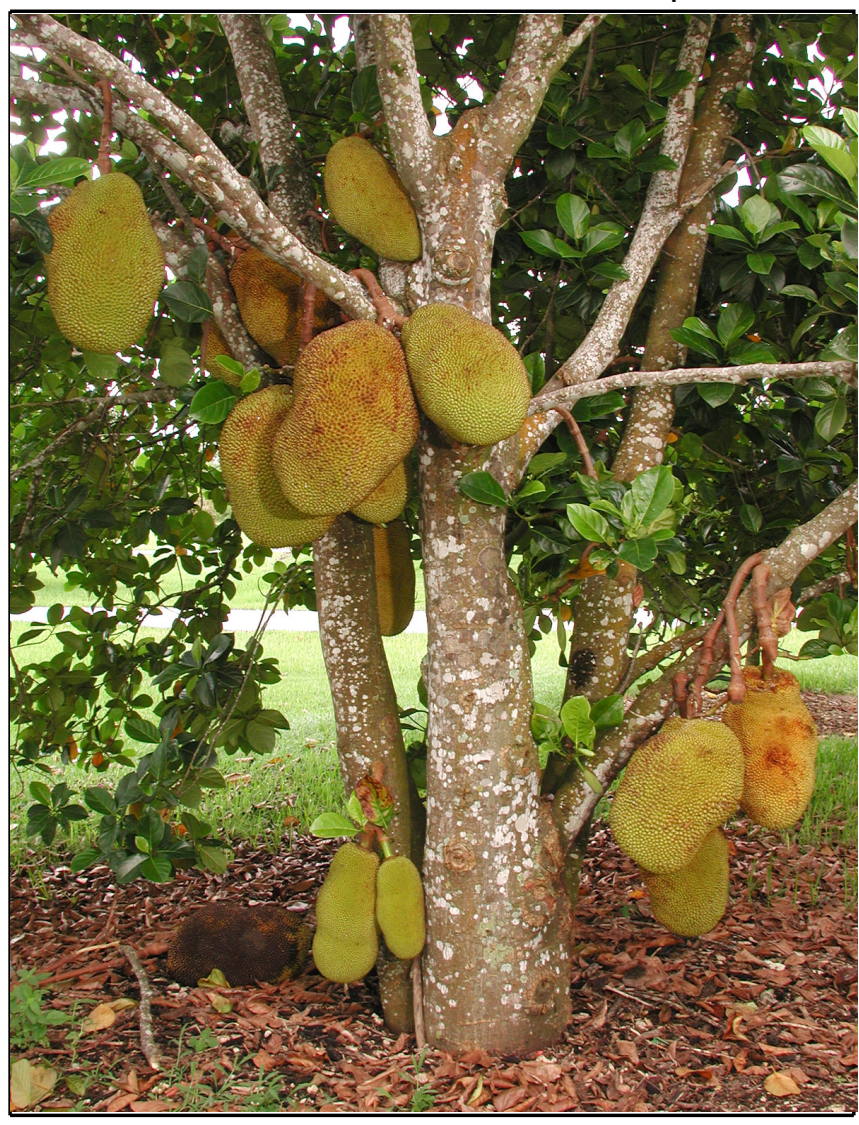

Seedling jakfruit. Credits: Ian Maguire IFAS/TREC

Other common names: English - jakfruit, jak; Spanish - jaca; Portuguese - jaca, jaqueira
Synonyms: Artocarpus integrifolius Auct.; A. integra Merr.

Family: Moraceae

Relatives in the same family: Breadfruit (Artocarpus altilis), fig (Ficus sp.), mulberry (Morus sp.), champedak (A. integer), kwai muk (A. lingnanensis), Ficus benjamina.

Origin: Probably India

Distribution: India, Myanmar, Sri Lanka, China, Malaysia, Philippines, Australia, Kenya, Uganda, and Mauritius. In the Americas it is not widely cultivated but is fairly important in Brazil, Jamaica, the Bahamas, south Florida, and Hawaii.

Importance: Jackfruit is important in India and other Asian countries like Sri Lanka, southern China, Malaysia, Myanmar. There is limited production in Australia, Mauritius, Brazil, Surinam, Jamaica, Mexico, Hawaii and south Florida.

\section{Botanical Description}

Tree. Erect, evergreen, fairly large tree, 30 to 40 feet (9-12 m) tall in Florida.

1. This document is Fact Sheet HS-882, one in a series of the Horticultural Sciences Department, Florida Cooperative Extension Service, Institute of Food and Agricultural Sciences, University of Florida. Publication date, May 2002. Please visit EDIS Web site at http://edis.ifas.ufl.edu

2. J.H. Crane, Professor, Tropical Fruit Crops Specialist, Tropical Research and Education Center, Homestead; C.F. Balerdi, Multicounty Tropical Fruit Crops Extension Agent III, Cooperative Extension Service, Institute of Food and Agricultural Sciences, Miami-Dade County, Homestead; and R.J. Campbell, Curator of Tropical Fruits, Fairchild Tropical Garden, Miami. 
Leaves. Dark green, alternate, glossy and somewhat leathery, fairly large and oval shaped on mature wood and deeply lobed on young shoots. All parts contain a sticky white latex.

Flowers. Short, stout flowering twigs emerge from the trunk and large branches. The tree is monoecious with small male flowers held by a thin pedicel. Female flowers are larger than the males and the pedicel is quite thick.

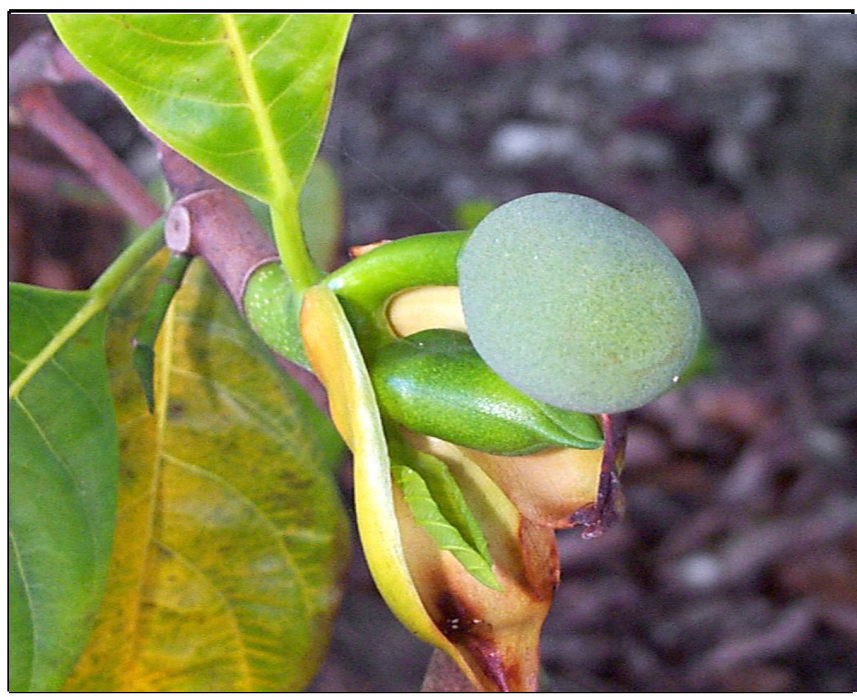

Figure 2.a Credits: Ian Maguire IFAS/TREC

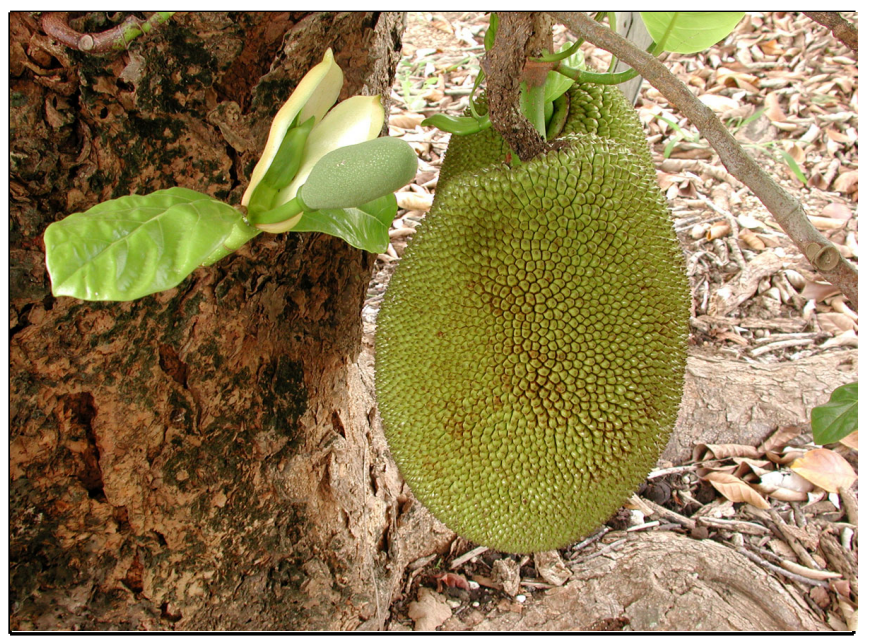

Figure 2.b Credits: Ian Maguire IFAS/TREC

\section{Jakfruit flower.}

Fruit. The jackfruit is a multiple fruit i.e., composed of the coherence of multiple flowers. Fruit is moderately large to very large, weighing from 10 to 60 pounds $(4.5-27.3 \mathrm{~kg})$. A few cultivars are small fruited, weighing 3 to 10 pounds $(1.4-4.5 \mathrm{~kg})$ each. The skin is extremely rough and thick. Fruit skin color is green when immature and green, greenish yellow to brownish-yellow when ripe. The inside of the fruit contains the edible, sweet, aromatic, crispy, soft or melting pulp that surrounds each seed. Between the seeds and edible pulp is the inedible "rag". Pulp color varies from amber to yellow, dark yellow or orange. Seeds are $3 / 4$ to $11 / 4$ inches ( 2 to 3 $\mathrm{cm})$ long, oval; the number per fruit varies from 30 to 500. The time from flowering to fruit maturity ranges from 150 to 180 days.

\section{Climate}

The jackfruit is well adapted to the hot humid tropics and grows well in the humid subtropical climate of south Florida where there are only occasional freezes. Optimum growth and production occurs in continuously warm areas. Jackfruit will grow from sea level to 5,000 feet (1524 m) elevation. However, quality is better at the lower elevations (up to 500-700 feet; $152-213 \mathrm{~m}$ ).

\section{Drought Stress}

Jackfruit trees are moderately drought tolerant. However, for optimum tree growth and fruit production trees should be irrigated during dry periods.

\section{Flooding Stress}

Jackfruit trees are not tolerant of continuously wet and/or flooded soil conditions. Trees may decline or die after 2 to 3 days of wet soil conditions.

\section{Cold Stress}

Jackfruit leaves may be damaged at $32^{\circ} \mathrm{F}\left(0^{\circ} \mathrm{C}\right)$, branches at $30^{\circ} \mathrm{F}\left(-1^{\circ} \mathrm{C}\right)$, and branches and trees may be killed at $28^{\circ} \mathrm{F}\left(-2^{\circ} \mathrm{C}\right)$.

\section{Wind Stress}

Jackfruit trees are tolerant of mild to moderately windy conditions. Trees have been observed to survive and recover from hurricane force winds with some limb damage. 


\section{Salt Stress}

There is only limited information of jackfruit tree tolerance to saline soil and/or water. Trees are probably not tolerant of saline conditions.

\section{Soils}

Trees grow best in well-drained soils. Trees tolerate sand, sandy loams and the rocky, well-drained, high $\mathrm{pH}$, calcareous soils of southern Florida.

\section{Propagation}

Jackfruit may be propagated by seed, grafting, and cuttings. In some areas, seed propagation is still used. Jackfruit from seed may be more precocious than many other fruit, and trees may begin production in the $3^{\text {rd }}$ to $4^{\text {th }}$ year. Seeds should be collected from trees that have regular, high yields and that also have good horticultural characters, such as insect, disease and nematode resistance, proper fruit size and excellent quality. Seeds are relatively short lived and may be stored up to about 30 days. In south Florida, seedlings and grafted trees are used.

In most new commercial plantings, grafted trees of known cultivars are preferred. Seedlings of 'NS-1' and 'Black Gold' jackfruit have been used as rootstock sources. For rootstocks, select vigorously growing seedlings that are healthy and eliminate stunted, yellow or chlorotic seedlings. Chip budding, side veneer grafting, cleft grafting, and approach grafting have been used, but mostly side veneer grafting. Select scions or budsticks from trees growing vigorously, preferably in the summer or fall. Cut bud sticks 4 to 6 inches $(10-15 \mathrm{~cm})$ long from shoot tips, remove all the leaves, and be sure that the terminal bud is swollen. Budwood may be prepared ahead of time by removing the tip and then collecting the scions when buds begin to swell, after a week or two. Bud or graft trees when the rootstocks are about pencil size in diameter. The tip of the terminal bud should be left uncovered when veneer grafting. Place grafted trees in a mist bed in partial shade. Jackfruit can also be propagated by air layers, but this method is not commonly used.
Jackfruit trees are greatly affected by root restriction (i.e., being pot bound) and develop a deeper and stronger root system if planted in large, deep, long (18-24 inches; 45-61 cm), plastic pots. When planted, pot-bound trees do not establish well and grow poorly. Large jackfruit trees (2-4 feet tall; 0.6-1.2 m) establish more quickly and grow better when planted out than do small trees.

Cuttings are not a common propagation method for jackfruit, nor have plants propagated in this manner been tested under field conditions. However, semi-hardwood cuttings with 3 leaves (leaves cut in half across the midrib) dipped in 5,000 to $10,000 \mathrm{ppm}$ IBA (1H-indole-3-butanoic acid) and placed in an intermittent mist bed will root in about 60 to 70 days.

\section{Production}

Jackfruit are wind and insect pollinated and generally require cross-pollination for satisfactory fruit production. Thus planting more than one cultivar is recommended. Mature jackfruit trees may produce from 40 to over 250 pounds (18-114 kg) per tree, depending on the cultivar, weather, and cultural practices. Trees that average 150 pounds $(68 \mathrm{~kg})$ per tree or more are considered good producers.

\section{Planting}

Planting may be done at anytime in south Florida provided there is an irrigation system to provide water for the newly planted trees and for frost and freeze protection. Otherwise, the best time to plant is in late spring or early summer, early in the rainy season.

Trees for planting are usually available in 3-gallon (11 liter) pots that are easy to handle. Make a hole wider than the pot; twice as large as the diameter of the pot is preferable. A handful or two of a well-decomposed organic matter can be mixed with the planting soil. Do not add fertilizer to the hole. Remove the tree from the pot without disturbing the root system and handle the tree carefully. Plant the tree at the same height it was in the pot. Fill the hole with the same soil that came out of the hole; do not use mulch or top soil in the hole. Water the tree well immediately after planting. Building a circular berm 
about 2 feet away from the trunk will facilitate concentrating the water around the root system. I

Water three times per week for a month or two if it does not rain. Thereafter, reduce watering to twice per week. Irrigation timing and rates may be improved by monitoring soil moisture with tensiometers.

\section{Plant Spacing}

At maturity, jackfruit are large trees. In commercial plantings tree spacing needs to allow for grove operations such as, mowing, spraying, weed control, and harvesting. In-row spacing may range from 15 to 25 feet (4.6-7.6 m) and between-row spacing from 20 to 25 feet (6.1-7.6 m). Closer in-row spacings may increase fruit production per acre early in the life of the plantings. However, as trees mature and begin competing for light, water, and nutrients, production may decline if tree size is not controlled. Removal of every other tree as the planting matures should be considered. Plantings at wider spacings delay tree-to-tree competition but production per acre will be lower during the early life of the grove. Tree rows should be oriented in a north-south direction if practical.

Jackfruit in the home landscape should be planted 25 to 30 feet $(7.6-9.1 \mathrm{~m})$ away from other trees and structures.

\section{Cultivars}

There is limited experience on the performance of jackfruit cultivars under commercial conditions; however, initial evaluation of a number of cultivars has been completed. Tables 1 and 2 show tree, fruit and pulp characteristics. Growers should plant several cultivars for further evaluation and then select the best for future plantings.

\section{Fertilizer Practices}

After new growth begins, spread 1/4 lb. (113 g) of fertilizer, such as 6-6-6 with minor elements and $30 \%$ of the nitrogen from organic sources, per tree. Repeat fertilizer applications every 6 to 8 weeks for the first year. Then, gradually increase the amount as the trees grow (Table 3). Apply 4 to 6-minor element (nutritional) sprays per tree per year, sprayed on the foliage from April to September. Apply a soil drench of chelated iron once or twice per year per tree from June through September. For calcareous soils use EDDHA (technical sodium ferric ethylenediamine di-(o-hydroxyphenylacetate) iron chelate, and for neutral and acid soils use EDTHA (technical sodium ferric diethylenetriamine pentaacetate) iron chelate.

For mature trees, fertilizer should be applied from bloom to right after harvesting and pruning. Chelated iron drenches are most effective from May to September, and foliar sprays from April to September.

\section{Irrigation Practices}

The water requirements of jackfruit have not been determined for south Florida. However, regular irrigation during dry periods is recommended for newly planted and young trees. For mature trees irrigation is recommended during dry periods and is critical from bloom through fruit development.

An irrigation system or a means of watering young trees should be available for newly planted and young trees. Under commercial production soil water content should be monitored to manage irrigation frequency and amounts. Tensiometers are instruments that measure soil moisture tension and are valuable for monitoring soil moisture levels and scheduling irrigation. Properly installed, placed, and maintained tensiometers may save water, fuel, and fertilizer and are recommended.

\section{Tree Training and Pruning}

\section{Young Trees}

Young jackfruit trees do not need pruning during their first year. Shoot tip pruning once or twice during spring and summer will force lateral bud break and make the tree more compact. Non-pruned trees usually develop a strong central leader. During the second season, trees should be pruned to the first lateral branch, which will slow upward growth and enhance spreading of the canopy. As trees mature, upright vigorous shoots should be removed and the inner canopy thinned out at the end of the harvest season. 


\section{Mature Trees}

Removal of selected upright, vigorously growing shoots is recommended. Removing the central leader to a weak lateral branch will slow upward growth and enhance lateral canopy development. Old flowering shoots should be removed after harvest.

For bearing trees, periodically remove (thin out) old limbs at the end of the harvest season to increase light penetration to the inner canopy. Tree height may be maintained at 8 to 14 feet by periodic selective pruning. Selective pruning may also be used to limit tree width to allow a 6 to $8 \mathrm{ft}$ drive middle for equipment traffic and grove operations. Trees may also be mechanically topped at 8 to 14 feet and hedged at a 5 to $10^{\circ}$ angle from the vertical.

\section{Fruit Thinning}

The number of fruit per tree or major limb should be limited to 1 on young trees, as heavy fruit loads have been observed to result in limb decline or death and tree stunting. On mature trees, limiting the number of fruit per major limb may enhance the quality and size of remaining fruit.

\section{Insect Pests, Diseases, and Disorders}

\section{Insect Pests}

There are a number of wood boring insects that may attack wounded or dead wood along the trunks and branches (Elaphidion mucronatum, Nyssodrysina haldemani, Leptostylopsis terraecolor). Various scales such as the lesser snow scale (Pinnaspis strachani), coconut scale (Aspidiotus destructor), mango shield scale (Protopulvinaria mangiferae), pyriform scale (Protopulvinaria pyrifomis) and mealybugs may attack stems and fruit. Please contact your local Agricultural Extension Agent for current control options.

\section{Diseases}

In general, jackfruit have few disease problems in south Florida. Male flowers and fruit may be attacked by Rhizopus fruit rot (Rhizopus artocarpi) and fruit by Gray mold (Botrytis cinerea). Trees are susceptible to root rot (Pythium splendens, Phytophthora sp., Fusarium sp., Rhizoctonia sp.) especially when subjected to flooding. Several fungi (i.e., Gloeosproium sp., Phyllosticta artocarpi) cause leaf spotting. Please contact your local Agricultural Extension Agent for current control options.

\section{Weed Control}

Weeds compete for water and nutrients and may slow tree establishment. Prior to planting trees in the home landscape, remove an 18 to 36 inch $(45-91 \mathrm{~cm})$ diameter ring of sod. After planting, keep grass away from the tree trunk. Placing a 2 to 4 inch $(5-10 \mathrm{~cm})$ thick layer of mulch several inches from the tree trunk out to the edge of the tree canopy will suppress weed and grass growth and hold soil moisture. Do not allow lawn mowers to hit the tree trunk and do not use a weed-eater near the tree trunk as this will damage the bark and weaken or kill the tree.

\section{Fruit Maturity, Harvest and Storage}

Jackfruit may be eaten as a vegetable when picked at an immature stage or eaten fresh when picked at a mature stage and allowed to ripen. Immature fruit is usually 1 to 3 months old, are green and may be harvested for cooking.

Mature fruit have 35 to $40 \%$ edible flesh. However, it is not easy to determine when the fruit is ripe. There are several fruit characteristics that may be used alone or together indicate a particular cultivar is mature. In many cultivars the skin color changes from green to light green or yellow. Maturing fruits usually develop a strong aroma and the peel spines flatten and widen. Green fruits have a solid sound when tapped whereas ripe fruits have a hollow sound.

Harvest fruit with clippers or loppers. The cut stem will immediately exude white, sticky latex; this latex will permanently stain clothing. Wrap the cut end with a paper towel to make handling easier, or set the fruit on its side until the flow of latex ceases. Care should be exercised not to let the fruit drop to the ground and be damaged. Pickers may want to wear gloves when handling the fruit. Place fruit in picking crates and in the shade until they are taken to the packinghouse. 
Mature fruit will ripen in 3 to 10 days at $75^{\circ} \mathrm{F}$ to $80^{\circ} \mathrm{F}\left(24-27^{\circ} \mathrm{C}\right)$. Before consumption the edible flesh is separated from the rag. As with harvesting, latex may exude from cut surfaces when extracting the flesh. To make clean-up easier coat hands, knives, and work surfaces with vegetable oil. To clean the fruit, cut in half and remove the central core; then proceed to separate the flesh, seed, and rag.

Cool temperatures $\left(<60^{\circ} \mathrm{F} ; 16^{\circ} \mathrm{C}\right)$ may delay ripening. The proper storage temperatures for jackfruit have not been determined. A storage temperature of $50^{\circ} \mathrm{F}\left(10^{\circ} \mathrm{C}\right)$ for several weeks has been tested but resulted in some damage to the ripening process and reduced fruit quality. Fully ripe fruit segments may be placed in polyethelyne bags and frozen for later use.

\section{Uses and Nutrition}

Jackfruit have a number of uses. Green, immature fruit may be used as a vegetable in cooking including soups, and baked dishes, and fried. The pulp of ripe fruit may be eaten fresh, dried, or preserved in syrup or used for salads. The seeds can be boiled and roasted (eaten as a nut) and have a chestnut flavor. Jackfruit is low in calories and fat and a good source of potassium and Vitamin A (Table 4). 
Table 1. Jackfruit cultivar characteristics.

\begin{tabular}{|c|c|c|c|c|c|c|c|}
\hline $\begin{array}{l}\text { Cultivar } \\
\text { and } \\
\text { origin }\end{array}$ & $\begin{array}{l}\text { Growth habit } \\
\text { and rate }\end{array}$ & $\begin{array}{c}\text { Fruit size } \\
\text { and } \\
\text { weight }\end{array}$ & $\begin{array}{l}\text { Fruit } \\
\text { shape }\end{array}$ & $\begin{array}{l}\text { Yield per } \\
\text { tree (lbs) }\end{array}$ & $\begin{array}{l}\text { Season } \\
\text { and } \\
\text { months }\end{array}$ & Photo & Comments \\
\hline $\begin{array}{l}\text { Black } \\
\text { Gold, } \\
\text { Australia }\end{array}$ & $\begin{array}{l}\text { Open, } \\
\text { spreading, fast }\end{array}$ & Med(Llas,)22 & $\begin{array}{l}\text { Long, } \\
\text { tapered }\end{array}$ & $\begin{array}{l}\text { Heavy, } \\
120-200\end{array}$ & $\begin{array}{l}\text { Late, } \\
\text { Sept.-Oct. }\end{array}$ & Photo & $\begin{array}{l}\text { Tree easily pruned to } \\
\text { maintain small tree }(\sim 8 \mathrm{ft})\end{array}$ \\
\hline $\begin{array}{l}\text { Cheena, } \\
\text { Australia }\end{array}$ & $\begin{array}{l}\text { Open, low } \\
\text { spreading, } \\
\text { moderate }\end{array}$ & Small, 5-10 & $\begin{array}{l}\text { Long, } \\
\text { narrow, } \\
\text { uniform }\end{array}$ & $\begin{array}{l}\text { Moderately } \\
\text { heavy, } \\
110-154\end{array}$ & $\begin{array}{l}\text { Mid, } \\
\text { July-Aug. }\end{array}$ & & $\begin{array}{l}\text { Hybrid with champedak ( } \mathrm{A} \text {. } \\
\text { integer); tree easily pruned } \\
\text { to maintain small tree }(\sim 8 \\
\mathrm{ft})\end{array}$ \\
\hline $\begin{array}{l}\text { Chompa } \\
\text { Gob }\end{array}$ & $\begin{array}{l}\text { Open, } \\
\text { spreading, fast }\end{array}$ & $\begin{array}{l}\text { Medium, } \\
12-20\end{array}$ & $\begin{array}{l}\text { Blocky, } \\
\text { uniform }\end{array}$ & $\begin{array}{l}\text { Moderately } \\
\text { heavy, } \\
90-120\end{array}$ & $\begin{array}{l}\text { Mid, } \\
\text { July-Aug. }\end{array}$ & & $\begin{array}{l}\text { Easily pruned to maintain } \\
\text { small tree size }\end{array}$ \\
\hline $\begin{array}{l}\text { Cochin, } \\
\text { Australia }\end{array}$ & $\begin{array}{l}\text { Sparse, } \\
\text { upright, slow }\end{array}$ & Small, 2-5 & $\begin{array}{l}\text { Round, } \\
\text { irregular }\end{array}$ & $\begin{array}{l}\text { Moderately } \\
\text { heavy, } \\
80-130\end{array}$ & $\begin{array}{l}\text { Early, } \\
\text { June-July }\end{array}$ & & $\begin{array}{l}\text { Thinning the number of fruit } \\
\text { recommended; tree easily } \\
\text { pruned to maintain small } \\
\text { tree }(\sim 8 \mathrm{ft})\end{array}$ \\
\hline $\begin{array}{l}\text { Dang } \\
\text { Rasimi, } \\
\text { Thailand }\end{array}$ & $\begin{array}{l}\text { Open, } \\
\text { spreading, fast }\end{array}$ & $\begin{array}{l}\text { Medium-larg } \\
\text { e, 18-20 }\end{array}$ & $\begin{array}{l}\text { Uniform } \\
\text { oblong }\end{array}$ & $\begin{array}{l}\text { Very } \\
\text { heavy, } \\
165-275\end{array}$ & $\begin{array}{l}\text { Mid, } \\
\text { July-Aug. }\end{array}$ & & $\begin{array}{l}\text { Vigorous tree; annual } \\
\text { pruning needed to maintain } \\
\text { moderate size }(\sim 11 \mathrm{ft})\end{array}$ \\
\hline $\begin{array}{l}\text { Gold } \\
\text { Nugget, } \\
\text { Australia }\end{array}$ & $\begin{array}{l}\text { Dense, } \\
\text { spreading, fast }\end{array}$ & Small, 7-12 & Round & $\begin{array}{l}\text { Heavy, } \\
132-176\end{array}$ & $\begin{array}{l}\text { Early, } \\
\text { May-June }\end{array}$ & Photo & $\begin{array}{l}\text { Thinning number of fruit } \\
\text { recommended; tree easily } \\
\text { pruned to maintain small } \\
\text { tree }(\sim 8 \mathrm{ft})\end{array}$ \\
\hline $\begin{array}{l}\text { Honey } \\
\text { Gold, } \\
\text { Australia }\end{array}$ & $\begin{array}{l}\text { Sparse, } \\
\text { spreading, } \\
\text { slow-moderate }\end{array}$ & $\begin{array}{l}\text { Small to } \\
\text { medium-sm } \\
\text { all, 10-12 }\end{array}$ & Blocky & $\begin{array}{l}\text { Moderate, } \\
77-110\end{array}$ & $\begin{array}{l}\text { Mid, } \\
\text { July-Aug. }\end{array}$ & & $\begin{array}{l}\text { Thinning number of fruit } \\
\text { recommended; tree easily } \\
\text { pruned to maintain small } \\
\text { tree }(\sim 8 \mathrm{ft})\end{array}$ \\
\hline $\begin{array}{l}\text { J-30, } \\
\text { Malaysia }\end{array}$ & $\begin{array}{l}\text { Vigorous, } \\
\text { open, conical, } \\
\text { fast }\end{array}$ & $\begin{array}{l}\text { Medium, } \\
17-25\end{array}$ & $\begin{array}{l}\text { Uniform, } \\
\text { oblong }\end{array}$ & $\begin{array}{l}\text { Moderately } \\
\text { heavy, } \\
110-132\end{array}$ & $\begin{array}{l}\text { Mid, } \\
\text { July-Aug. }\end{array}$ & & $\begin{array}{l}\text { Vigorous tree; annual } \\
\text { pruning needed to maintain } \\
\text { moderate size }(\sim 10 \mathrm{ft})\end{array}$ \\
\hline $\begin{array}{l}\text { J-31, } \\
\text { Malaysia }\end{array}$ & $\begin{array}{l}\text { Open, } \\
\text { spreading, fast }\end{array}$ & Large, 26 & Irregular & $\begin{array}{l}\text { Moderately } \\
\text { heavy, } \\
92-132\end{array}$ & $\begin{array}{l}\text { Early, } \\
\text { May-June }\end{array}$ & & $\begin{array}{l}\text { Often off-season fruit; tree } \\
\text { easily pruned to maintain } \\
\text { small tree }(\sim 8 \mathrm{ft})\end{array}$ \\
\hline $\begin{array}{l}\text { Kun Wi } \\
\text { Chan, } \\
\text { Thailand }\end{array}$ & $\begin{array}{l}\text { Vigorous, } \\
\text { dense, fast }\end{array}$ & Large, 33-40 & $\begin{array}{l}\text { Uniform, } \\
\text { round }\end{array}$ & $\begin{array}{l}\text { Very } \\
\text { heavy, } 242\end{array}$ & $\begin{array}{l}\text { Mid, } \\
\text { July-Aug. }\end{array}$ & Photo & $\begin{array}{l}\text { Vigorous tree; annual } \\
\text { pruning needed to maintain } \\
\text { moderate size }(\sim 13 \mathrm{ft})\end{array}$ \\
\hline $\begin{array}{l}\text { Lemon } \\
\text { Gold, } \\
\text { Australia }\end{array}$ & $\begin{array}{l}\text { Moderately } \\
\text { dense, } \\
\text { spreading, } \\
\text { moderate }\end{array}$ & $\begin{array}{l}\text { Medium-sm } \\
\text { all, } 13\end{array}$ & Blocky & $\begin{array}{l}\text { Moderate, } \\
66-100\end{array}$ & $\begin{array}{l}\text { Mid, } \\
\text { July-Aug. }\end{array}$ & & $\begin{array}{l}\text { Vigorous tree; annual } \\
\text { pruning needed to maintain } \\
\text { moderate size }(\sim 12 \mathrm{ft})\end{array}$ \\
\hline
\end{tabular}


Table 1. Jackfruit cultivar characteristics.

\begin{tabular}{||l|l|l|l|l|l|l|l}
\hline \hline $\begin{array}{l}\text { NS1, } \\
\text { Malaysia }\end{array}$ & $\begin{array}{l}\text { Dense, } \\
\text { upright, } \\
\text { moderate }\end{array}$ & $\begin{array}{l}\text { Small to } \\
\text { medium-sm } \\
\text { all, 9-12 }\end{array}$ & Blocky & Heavy, 200 & $\begin{array}{l}\text { Early, } \\
\text { May-June }\end{array}$ & $\begin{array}{l}\text { Thinning number of fruit } \\
\text { recommended for young } \\
\text { trees; moderately vigorous } \\
\text { tree; annual pruning to } \\
\text { maintain moderate size } \\
(\sim 10 \mathrm{ft})\end{array}$ \\
\hline $\begin{array}{l}\text { Tabouey, } \\
\text { Indonesia }\end{array}$ & $\begin{array}{l}\text { Open, } \\
\text { rounded, } \\
\text { slow-moderate }\end{array}$ & $\begin{array}{l}\text { Medium-larg } \\
\text { e to large, } \\
20-25\end{array}$ & $\begin{array}{l}\text { Long, } \\
\text { tapered }\end{array}$ & $\begin{array}{l}\text { Moderately } \\
\text { heavy, } \\
110-154\end{array}$ & $\begin{array}{l}\text { Late, } \\
\text { Sept.-Oct. }\end{array}$ & $\begin{array}{l}\text { Thinning number of fruit } \\
\text { recommended for young } \\
\text { trees; moderately vigorous } \\
\text { tree; annual pruning to } \\
\text { maintain moderate size } \\
(~ 10 \mathrm{ft})\end{array}$ \\
\hline \hline
\end{tabular}

Table 2. Pulp characteristics of jackfruit cultivars.

\begin{tabular}{|c|c|c|c|c|c|c|c|}
\hline Cultivar & Color & Texture & $\begin{array}{c}\text { Flat } \\
\text { spines at } \\
\text { ripening }\end{array}$ & $\begin{array}{l}\% \text { edible } \\
\text { flesh }\end{array}$ & $\begin{array}{c}\text { \# seeds } \\
\text { per fruit; } \\
\text { seed } \%\end{array}$ & Quality & Comments \\
\hline $\begin{array}{l}\text { Black } \\
\text { Gold }\end{array}$ & $\begin{array}{l}\text { Deep } \\
\text { orange }\end{array}$ & $\begin{array}{l}\text { Medium-firm } \\
\text { to melting, } \\
\text { soft }\end{array}$ & No & 35 & $192 ; 17$ & $\begin{array}{l}\text { Good, } \\
\text { sweet, } \\
\text { aromatic }\end{array}$ & $\begin{array}{l}\text { Flesh easily } \\
\text { removed }\end{array}$ \\
\hline Cheena & $\begin{array}{l}\text { Deep } \\
\text { orange }\end{array}$ & $\begin{array}{l}\text { Soft, melting, } \\
\text { somewhat } \\
\text { fibrous }\end{array}$ & Yes & 33 & $38 ; 11$ & $\begin{array}{l}\text { Excellent, } \\
\text { very } \\
\text { aromatic }\end{array}$ & $\begin{array}{l}\text { Flesh easily } \\
\text { removed }\end{array}$ \\
\hline Cochin & $\begin{array}{l}\text { Yellow to } \\
\text { orange }\end{array}$ & $\begin{array}{l}\text { Firm to } \\
\text { crunchy }\end{array}$ & Yes & $35-50$ & $35 ; 7$ & Good, mild & $\begin{array}{l}\text { Sometimes "rag" } \\
\text { edible }\end{array}$ \\
\hline $\begin{array}{l}\text { Chompa } \\
\text { Gob }\end{array}$ & Orange & Firm & Yes & 30 & $200 ; 7$ & $\begin{array}{l}\text { Good, } \\
\text { mild flavor }\end{array}$ & $\begin{array}{l}\text { Texture of } \\
\text { excellent quality }\end{array}$ \\
\hline $\begin{array}{l}\text { Dang } \\
\text { Rasimi }\end{array}$ & $\begin{array}{l}\text { Deep } \\
\text { orange }\end{array}$ & Firm to soft & No & 32 & $187 ; 12$ & $\begin{array}{l}\text { Mild, } \\
\text { sweet } \\
\text { flavor, } \\
\text { pleasant }\end{array}$ & Flesh thin walled \\
\hline $\begin{array}{l}\text { Golden } \\
\text { Nugget }\end{array}$ & $\begin{array}{l}\text { Deep } \\
\text { orange }\end{array}$ & $\begin{array}{l}\text { Soft to } \\
\text { medium firm }\end{array}$ & Yes & 41 & $79 ; 13$ & $\begin{array}{l}\text { 탖ece用ent } \\
\text { flavor }\end{array}$ & $\begin{array}{l}\text { Fruit may split } \\
\text { after heavy rains }\end{array}$ \\
\hline $\begin{array}{l}\text { Honey } \\
\text { Gold }\end{array}$ & $\begin{array}{l}\text { Dark } \\
\text { yellow to } \\
\text { orange }\end{array}$ & Firm & Yes & 36 & $42 ; 5$ & $\begin{array}{l}\text { Sweet, } \\
\text { rich flavor } \\
\text { and aroma }\end{array}$ & $\begin{array}{l}\text { Flesh thick } \\
\text { walled, excellent } \\
\text { texture }\end{array}$ \\
\hline $\mathrm{J}-30$ & $\begin{array}{l}\text { Deep } \\
\text { orange }\end{array}$ & Firm & Yes & 38 & $200 ; 9$ & $\begin{array}{l}\text { Sweet rich } \\
\text { flavor and } \\
\text { aroma }\end{array}$ & $\begin{array}{l}\text { Flesh thick } \\
\text { walled, excellent } \\
\text { texture }\end{array}$ \\
\hline $\mathrm{J}-31$ & $\begin{array}{l}\text { Deep } \\
\text { yellow }\end{array}$ & Firm & Yes & 36 & $180 ; 18$ & $\begin{array}{l}\text { Sweet rich } \\
\text { flavor, } \\
\text { earthy } \\
\text { aroma }\end{array}$ & $\begin{array}{l}\text { Fruit rarely splits, } \\
\text { excellent texture }\end{array}$ \\
\hline
\end{tabular}


Table 2. Pulp characteristics of jackfruit cultivars.

\begin{tabular}{||l|l|l|l|l|l|l|l||}
\hline \hline $\begin{array}{l}\text { Kun Wi } \\
\text { Chan }\end{array}$ & Yellow & $\begin{array}{l}\text { Moderately } \\
\text { firm to soft }\end{array}$ & No & 29 & $210 ; 11$ & $\begin{array}{l}\text { Mild, } \\
\text { pleasant } \\
\text { flavor }\end{array}$ \\
\hline $\begin{array}{l}\text { Lemon } \\
\text { Gold }\end{array}$ & $\begin{array}{l}\text { Lemon } \\
\text { yellow } \\
\text { considered of } \\
\text { mediocre quality }\end{array}$ & Firm & Yes & 37 & $104 ; 14$ & $\begin{array}{l}\text { Sweet and } \\
\text { aromatic } \\
\text { flavor }\end{array}$ & Flesh thick walled \\
\hline NS1 & $\begin{array}{l}\text { Dark } \\
\text { orange }\end{array}$ & Firm & Yes & 34 & $63 ; 5$ & $\begin{array}{l}\text { Sweet rich } \\
\text { flavor }\end{array}$ & Excellent texture \\
\hline Tabouey & Light \\
yellow & Firm & No & 40 & $250 ; 12$ & $\begin{array}{l}\text { Mild, } \\
\text { pleasant } \\
\text { flavor, very } \\
\text { little aroma }\end{array}$ \\
\hline \hline
\end{tabular}

Table 3. Fertilizer recommendations for jackfruit in Florida.

\begin{tabular}{|c|c|c|c|c|c|}
\hline Year & $\begin{array}{l}\text { Times } \\
\text { per year }\end{array}$ & $\begin{array}{l}\text { Amount } \\
\text { per tree } \\
\text { (lbs) }^{1}\end{array}$ & $\begin{array}{c}\text { Total } \\
\text { amount per } \\
\text { tree (lbs) }\end{array}$ & $\begin{array}{c}\text { No. of minor } \\
\text { element sprays } \\
\text { per year }^{3}\end{array}$ & $\begin{array}{l}\text { Chelated iron } \\
\text { soil drenches } \\
\text { (oz/tree/year) }^{4}\end{array}$ \\
\hline 1 & 6 & $0.25-0.5$ & $1.5-3.0$ & 6 & $0.5-0.75$ \\
\hline 2 & 6 & $0.5-1.0$ & $3.0-6.0$ & 6 & $0.75-1.0$ \\
\hline 3 & 6 & $1.0-1.5$ & $6.0-9.0$ & 6 & $1.0-1.5$ \\
\hline 4 & 4 & $1.5-2.5$ & $9.0-10.0$ & 6 & $1.5-2$ \\
\hline 5 & 4 & $2.5-3.5$ & $10.0-14.0$ & $4-6$ & $2-4$ \\
\hline 6 & 4 & $3.5-4.0$ & $14.0-16.0$ & $4-6$ & $2-4$ \\
\hline 7 & 4 & $4.0-4.5$ & $16.0-18.0$ & $4-6$ & $2-4$ \\
\hline 8 & 4 & $4.5-5$ & $18.0-20.0$ & $4-6$ & $2-4$ \\
\hline \multicolumn{6}{|c|}{$\begin{array}{l}\text { 1, Amount per tree per application. Use } 6-6-6 \text { or } 8-3-9 \text { or slow release fertilizer material. } \\
2 \text {, Total amount per tree per year. } \\
3 \text {, Foliar sprays should contain zinc, manganese, boron, molybedenum, and possibly } \\
\text { magnesium. } \\
4 \text {, Chelated iron soil drenches may prevent iron deficiency. Foilar iron sprays are not generally } \\
\text { effective. }\end{array}$} \\
\hline
\end{tabular}


Table 4. Nutrient value of $100 \mathrm{~g}$ (3.5 oz) of fresh jackfruit.

\begin{tabular}{|c|c|c|c|}
\hline Constituent & $\begin{array}{l}\text { Approximate } \\
\text { value }\end{array}$ & Constituent & $\begin{array}{l}\text { Approximate } \\
\text { value }\end{array}$ \\
\hline Water content & $73 \%$ & Iron & $0.6 \mathrm{mg}$ \\
\hline Calories & $94 \mathrm{kcal}$ & Magnesium & $37.0 \mathrm{mg}$ \\
\hline Protein & $1.5 \mathrm{~g}$ & Phosphorus & $36.0 \mathrm{mg}$ \\
\hline Fat & $0.3 \mathrm{~g}$ & Potassium & $303.0 \mathrm{mg}$ \\
\hline Cholesterol & $0 \mathrm{~g}$ & Sodium & $3.0 \mathrm{mg}$ \\
\hline Carbohydrate & $24.0 \mathrm{~g}$ & Vitamin C & $6.7 \mathrm{mg}$ \\
\hline $\begin{array}{l}\text { Total dietary } \\
\text { fiber }\end{array}$ & $1.6 \mathrm{~g}$ & Vitamin A & 297 IU \\
\hline
\end{tabular}

